\title{
Echocardiography in takotsubo cardiomyopathy; a useful approach?
}

\author{
E. E. van der Wall • E. R. Holman - A. J. Scholte • \\ J. J. Bax
}

Received: 30 March 2010/Accepted: 2 April 2010/Published online: 14 April 2010

(C) The Author(s) 2010. This article is published with open access at Springerlink.com

Over the past years, echocardiography has been shown to play a pivotal role in the accurate evaluation of left ventricular function particularly in patients with ischemic heart disease and various manifestations of cardiomyopathy [1]. The ability to rapidly perform bedside echocardiography with EchoDoppler imaging places this modality in the heart of clinical research to understand cardiac function and to quantify various associated abnormalities. Echocardiography has found a major niche in visualizing left ventricular function in diverse manifestions of cardiomyopathies. For instance, widespread use of echocardiography has contributed to more frequent recognition of takotsubo stress cardiomyopathy [1-3]. Takotsubo cardiomyopathy has recently been recognized in patients with typical signs of acute myocardial infarction mostly due to emotional stress [4]. The disease may mimic an acute coronary syndrome and the acute course can be complicated by heart failure, arrhythmias, dynamic left ventricular outflow tract obstruction, hypotension and death [5]. In these patients the coronary arteries appear normal

Editorial comment on to the article of Chockaligam et al. (doi: 10.1007/s10554-010-9590-7).

E. E. van der Wall $(\bowtie) \cdot$ E. R. Holman .

A. J. Scholte · J. J. Bax

Leiden University Medical Center,

Leiden, The Netherlands

e-mail: E.E.van_der_Wall@lumc.nl but they show reversible wall motion abnormalities $[6,7]$.

In the current issue of the International Journal of Cardiovascular Imaging, Chockaligam et al. [8] nicely reviewed the clinical presentation of takotsubo stress cardiomyopathy and proposed a unified diagnostic algorithm for cardiologists acutely managing this cardiac emergency. Also the pivotal role of echocardiography was emphasized and the nuances of this peculiar acute cardiomyopathy from an echocardiographers' perspective were put forward. Accurate evaluation by echocardiography may assist in refining the diagnosis of takotsubo cardiomyopathy and to unravel its pathophysiological mechanism. The diagnosis of stress cardiomyopathy appears appropriate when angiography reveals no culprit lesions and left ventricular apical ballooning is typically seen. For example, at first sight, stress cardiomyopathy appears like an evolving left anterior descending infarction with akinesia of the apex, apical anterior wall and septum. At a closer view of the two-dimensional images from the apical four- and two chamber views, typical stress cardiomyopathy manifests as symmetrical regional wall motion abnormalities extending equally into the apical inferior and lateral walls. However, the definitive diagnosis of stress cardiomyopathy is confirmed when echocardiography repeated after few days to weeks shows complete normalization of regional wall motion abnormalities and left ventricular ejection fraction. Interestingly, the authors also revealed that about $25 \%$ of patients 
with stress cardiomyopathy very likely manifest left ventricular outflow tract obstruction. Loading conditions may significantly alter the severity of left ventricular outflow tract obstruction which may be a transient phenomenon. Left ventricular outflow tract obstruction can be precipitated when a small left ventricle develops hypercontractility, especially in the basal segments. This may lead to acute systolic subendocardial wall stress. This left ventricular strain consisting of both the systolic blood pressure and increased wall stress may result in myocardial stunning and cause the acute ballooning syndrome. Also advanced echocardiographic techniques such as tissue Doppler imaging, regional strain imaging and time-volume curves from three-dimensional echo image modeling may offer visually better demonstration of the regional wall motion abnormalities of stress cardiomyopathy with higher diagnostic sensitivity. Lastly, transesophageal echocardiography may provide anatomic details that may direct repair or replacement of the mitral apparatus when significant MR persists after stress cardiomyopathy and left ventricular outflow tract obstruction have resolved.

As also mentioned by the authors, magnetic resonance imaging (MRI) has become an important imaging modality in patients with a broad spectrum of cardiomyopathies [2, 9-56], in particular in patients with takotsubo cardiomyopathy [57-61]. In a recent study, the value of MRI has been shown by using its capability of myocardial tissue characterization [57]. At coronary angiography all patients showed normal coronary arteries; four patients had apical ballooning and four patients had midwall- or basal ballooning. MRI was performed at hospital admission and the images were analyzed with commercially available software (QMASS MR Version 6.2.1, Medis, Leiden, the Netherlands). A T2weighted imaging technique was used and it was found that T2-signal intensity was significantly higher in the dysfunctional segments, potentially indicating the presence of myocardial edema in the affected areas that showed ballooning. In the five patients who had a 2-3 week follow-up MRI scan, there was normalization of the wall motion abnormalities associated with a significant reduction in $\mathrm{T} 2$ signal intensity. As a result, it might be of great interest to know the pathophysiological condition of the affected myocardial tissue in the setting of the acute myocardial infarction in patients with stress cardiomyopathy. Both echocardiography- and MRIderived parameters may therefore be of great significance in the follow-up of these patients as they may show spontaneous recovery of the cardiac abnormalities.

To summarize, both echocardiography and MRI have their own specific value in the evaluation of patients with takotsubo cardiomyopathy. Of course, echocardiography, by virtue of its versatility and accessibility, wlll remain the first imaging modality of choice in routine clinical practice.

Open Access This article is distributed under the terms of the Creative Commons Attribution Noncommercial License which permits any noncommercial use, distribution, and reproduction in any medium, provided the original author(s) and source are credited.

\section{References}

1. Bleeker GB, Schalij MJ, Boersma E et al (2007) Relative merits of M-mode echocardiography and tissue Doppler imaging for prediction of response to cardiac resynchronization therapy in patients with heart failure secondary to ischemic or idiopathic dilated cardiomyopathy. Am J Cardiol 99:68-74

2. Bleeker GB, Bax JJ, Fung JW et al (2006) Clinical versus echocardiographic parameters to assess response to cardiac resynchronization therapy. Am J Cardiol 97:260-263

3. Bleeker GB, Holman ER, Steendijk P et al (2006) Cardiac resynchronization therapy in patients with a narrow QRS complex. J Am Coll Cardiol 48:2243-2250

4. Abdelmoneim SS, Mankad SV, Bernier M et al (2009) Microvascular function in Takotsubo cardiomyopathy with contrast echocardiography: prospective evaluation and review of literature. J Am Soc Echocardiogr 22:1249-1255

5. Scholte AJ, Bax JJ, Stokkel MP et al (2006) Multimodality imaging to diagnose takotsubo cardiomyopathy. J Nucl Cardiol 13:123-126

6. Alizadeh Dehnavi R, van der Wall EE (2005) Transient left ventricular apical ballooning. Ann Intern Med 142:678

7. Alizadeh Dehnavi R, van der Wall EE, Smits PC (2006) Left ventricular apical ballooning. Int J Cardiovasc Imaging 22:327-331

8. Chockalingam A, Xie GY, Dellsperger KC (2010, Feb 2) Echocardiography in stress cardiomyopathy and acute LVOT obstruction. Int J Cardiovasc Imaging [Epub ahead of print]

9. Holman ER, Buller VG, de Roos A et al (1997) Detection and quantification of dysfunctional myocardium by magnetic resonance imaging. A new three-dimensional method for quantitative wall-thickening analysis. Circulation 95:924-931

10. Schuijf JD, Bax JJ, Shaw LJ et al (2006) Meta-analysis of comparative diagnostic performance of magnetic resonance 
imaging and multislice computed tomography for noninvasive coronary angiography. Am Heart J 151:404-411

11. Ypenburg C, van der Wall EE, Schalij MJ, Bax JJ (2008) Imaging in cardiac resynchronisation therapy. Neth Heart J 16:S36-S40

12. van Rugge FP, van der Wall EE, Bruschke AV (1992) New developments in pharmacologic stress imaging. Am Heart J 124:468-485

13. van Rugge FP, Holman ER, van der Wall EE et al (1993) Quantitation of global and regional left ventricular function by cine magnetic resonance imaging during dobutamine stress in normal human subjects. Eur Heart J 14:456-463

14. Pluim BM, Lamb HJ, Kayser HW, Leujes F et al (1998) Functional and metabolic evaluation of the athlete's heart by magnetic resonance imaging and dobutamine stress magnetic resonance spectroscopy. Circulation 97:666-672

15. van Rugge FP, van der Wall EE, Spanjersberg SJ et al (1994) Magnetic resonance imaging during dobutamine stress for detection and localization of coronary artery disease. Quantitative wall motion analysis using a modification of the centerline method. Circulation 90:127-138

16. Nemes A, Geleijnse ML, van Geuns RJ et al (2008) Dobutamine stress MRI versus threedimensional contrast echocardiography: it's all black and white. Neth Heart J 16:217-218

17. Schuijf JD, Bax JJ, van der Wall EE (2007) Anatomical and functional imaging techniques: basically similar or fundamentally different? Neth Heart J 15:43-44

18. Vliegen HW, Doornbos J, de Roos A, Jukema JW, Bekedam MA, van der Wall EE (1997) Value of fast gradient echo magnetic resonance angiography as an adjunct to coronary arteriography in detecting and confirming the course of clinically significant coronary artery anomalies. Am J Cardiol 79:773-776

19. Hoogendoorn LI, Pattynama PM, Buis B, van der Geest RJ, van der Wall EE, de Roos A (1995) Noninvasive evaluation of aortocoronary bypass grafts with magnetic resonance flow mapping. Am J Cardiol 75:845-848

20. Langerak SE, Vliegen HW, de Roos A et al (2002) Detection of vein graft disease using high-resolution magnetic resonance angiography. Circulation 105:328333

21. Rebergen SA, Ottenkamp J, Doornbos J, van der Wall EE, Chin JG, de Roos A (1993) Postoperative pulmonary flow dynamics after Fontan surgery: assessment with nuclear magnetic resonance velocity mapping. J Am Coll Cardiol 21:123-131

22. Groenink M, Lohuis TA, Tijssen JG et al (1999) Survival and complication free survival in Marfan's syndrome: implications of current guidelines. Heart 82:499-504

23. Tulevski II, Hirsch A, Sanson BJ et al (2001) Increased brain natriuretic peptide as a marker for right ventricular dysfunction in acute pulmonary embolism. Thromb Haemost 86:1193-1196

24. Niezen RA, Helbing WA, van der Wall EE, van der Geest RJ, Rebergen SA, de Roos A (1996) Biventricular systolic function and mass studied with MR imaging in children with pulmonary regurgitation after repair for tetralogy of Fallot. Radiology 201:135-140

25. Vliegen HW, van Straten A, de Roos A et al (2002) Magnetic resonance imaging to assess the hemodynamic effects of pulmonary valve replacement in adults late after repair of tetralogy of fallot. Circulation 106:1703-1707

26. Oosterhof T, van Straten A, Vliegen HW et al (2007) Preoperative thresholds for pulmonary valve replacement in patients with corrected tetralogy of Fallot using cardiovascular magnetic resonance. Circulation 116:545-551

27. van der Geest RJ, de Roos A, van der Wall EE, Reiber JH (1997) Quantitative analysis of cardiovascular MR images. Int J Card Imaging 13:247-258

28. van der Geest RJ, Niezen RA, van der Wall EE, de Roos A, Reiber JH (1998) Automated measurement of volume flow in the ascending aorta using MR velocity maps: evaluation of inter- and intraobserver variability in healthy volunteers. J Comput Assist Tomogr 22:904-911

29. van der Laarse A, Kerkhof PL, Vermeer F et al (1988) Relation between infarct size and left ventricular performance assessed in patients with first acute myocardial infarction randomized to intracoronary thrombolytic therapy or to conventional treatment. Am J Cardiol 61:1-7

30. van der Wall EE, Vliegen HW, de Roos A, Bruschke AV (1995) Magnetic resonance imaging in coronary artery disease. Circulation 92:2723-2739

31. Bavelaar-Croon CD, Kayser HW, van der Wall EE et al (2000) Left ventricular function: correlation of quantitative gated SPECT and MR imaging over a wide range of values. Radiology 217:572-575

32. Bax JJ, Lamb H, Dibbets P et al (2000) Comparison of gated single-photon emission computed tomography with magnetic resonance imaging for evaluation of left ventricular function in ischemic cardiomyopathy. Am J Cardiol 86:1299-1305

33. Posma JL, Blanksma PK, van der Wall EE, Hamer HP, Mooyaart EL, Lie KI (1996) Assessment of quantitative hypertrophy scores in hypertrophic cardiomyopathy: magnetic resonance imaging versus echocardiography. Am Heart J 132:1020-1027

34. Pluim BM, Beyerbacht HP, Chin JC et al (1997) Comparison of echocardiography with magnetic resonance imaging in the assessment of the athlete's heart. Eur Heart J 18:1505-1513

35. Pluim BM, Chin JC, De Roos A et al (1996) Cardiac anatomy, function and metabolism in elite cyclists assessed by magnetic resonance imaging and spectroscopy. Eur Heart J 17:1271-1278

36. van der Wall EE, den Hollander W, Heidendal GA, Westera G, Majid PA, Roos JP (1981) Dynamic myocardial scintigraphy with 123I-labeled free fatty acids in patients with myocardial infarction. Eur J Nucl Med 6:383-389

37. Braun S, van der Wall EE, Emanuelsson S, Kobrin I (1996) Effects of a new calcium antagonist, mibefradil (Ro 405967), on silent ischemia in patients with stable chronic angina pectoris: a multicenter placebo-controlled study. The mibefradil international study group. J Am Coll Cardiol 27:317-322

38. de Roos A, Matheijssen NA, Doornbos J et al (1990) Myocardial infarct size after reperfusion therapy: assessment with Gd-DTPA-enhanced MR imaging. Radiology 176:517-521

39. de Roos A, Matheijssen NA, Doornbos J, van Dijkman PR, van Rugge PR, van der Wall EE (1991) Myocardial infarct sizing and assessment of reperfusion by magnetic 
resonance imaging: a review. Int $\mathbf{J}$ Card Imaging 7: 133-138

40. van Rugge FP, Boreel JJ, van der Wall EE et al (1991) Cardiac first-pass and myocardial perfusion in normal subjects assessed by sub-second Gd-DTPA enhanced MR imaging. J Comput Assist Tomogr 15:959-965

41. van Rugge FP, van der Wall EE, van Dijkman PR, Louwerenburg HW, de Roos A, Bruschke AV (1992) Usefulness of ultrafast magnetic resonance imaging in healed myocardial infarction. Am J Cardiol 70:1233-1237

42. Holman ER, van Jonbergen HP, van Dijkman PR, van der Laarse A, de Roos A, van der Wall EE (1993) Comparison of magnetic resonance imaging studies with enzymatic indexes of myocardial necrosis for quantification of myocardial infarct size. Am J Cardiol 71:1036-1040

43. Buller VG, van der Geest RJ, Kool MD, van der Wall EE, de Roos A, Reiber JH (1997) Assessment of regional left ventricular wall parameters from short axis magnetic resonance imaging using a three-dimensional extension to the improved centerline method. Invest Radiol 32:529-539

44. Holman ER, van Rossum AC, Doesburg T, van der Wall EE, de Roos A, Visser CA (1996) Assessment of acute myocardial infarction in man with magnetic resonance imaging and the use of a new paramagnetic contrast agent gadolinium-BOPTA. Magn Reson Imaging 14:21-29

45. Krauss XH, Van der Wall EE, Doornbos J et al (1989) Value of magnetic resonance imaging in patients with a recent myocardial infarction: comparison with planar thallium-201 scintigraphy. Cardiovasc Intervent Radiol 12:119-124

46. van der Wall EE, Bax JJ (2008) Late contrast enhancement by CMR: more than scar? Int J Cardiovasc Imaging 24:609-611

47. Bakx AL, van der Wall EE, Braun S, Emanuelsson H, Bruschke AV, Kobrin I (1995) Effects of the new calcium antagonist mibefradil (Ro 40-5967) on exercise duration in patients with chronic stable angina pectoris: a multicenter, placebo-controlled study. Ro 40-5967 International Study Group. Am Heart J 130:748-757

48. de Nooijer R, Verkleij CJ, von der Thüsen JH et al (2006) Lesional overexpression of matrix metalloproteinase-9 promotes intraplaque hemorrhage in advanced lesions but not at earlier stages of atherogenesis. Arterioscler Thromb Vasc Biol 26:340-346

49. Nijveldt R, Beek AM, Hirsch A et al (2008) 'No-reflow' after acute myocardial infarction: direct visualisation of microvascular obstruction by gadolinium-enhanced CMR. Neth Heart J 16:179-181
50. van der Hoeven BL, Pires NM, Warda HM et al (2005) Drug-eluting stents: results, promises and problems. Int $\mathbf{J}$ Cardiol 99:9-17

51. Ypenburg C, Roes SD, Bleeker GB et al (2007) Effect of total scar burden on contrast-enhanced magnetic resonance imaging on response to cardiac resynchronization therapy. Am J Cardiol 99:657-660

52. van der Laan A, Hirsch A, Nijveldt R et al (2008) Bone marrow cell therapy after acute myocardial infarction: the HEBE trial in perspective, first results. Neth Heart J $16: 436-439$

53. Higgins CB, Herfkens R, Lipton MJ et al (1983) Nuclear magnetic resonance imaging of acute myocardial infarction in dogs: alterations in magnetic resonance times. Am J Cardiol 52:184-188

54. Matheijssen NA, de Roos A, van der Wall EE et al (1991) Acute myocardial infarction: comparison of T2-weighted and T1-weighted gadolinium-DTPA enhanced MR imaging. Magn Reson Med 17:460-469

55. Krauss XH, van der Wall EE, van der Laarse A et al (1990) Follow-up of regional myocardial $\mathrm{T} 2$ relaxation times in patients with myocardial infarction evaluated with magnetic resonance imaging. Eur J Radiol 11:110-119

56. Choi SH, Kang J-W, Kim S-T et al (2009) Investigation of T2-weighted signal intensity of infarcted myocardium and its correlation with delayed enhancement magnetic resonance imaging in a porcine model with reperfused acute myocardial infarction. Int J Cardiovasc Imaging 25(Suppl 1):111-119

57. Joshi SB, Chao T, Herzka DA et al (2010) Cardiovascular magnetic resonance $\mathrm{T} 2$ signal abnormalities in left ventricular ballooning syndrome. Int $\mathbf{J}$ Cardiovasc Imaging 26:227-232

58. Gurlek C, van Es J, van der Burgh PH, Galjee MA, van Birgelen C (2007) Full pattern of transient apical ballooning of the left ventricle triggered by minor myocardial infarction. Neth Heart J 15:310-311

59. Singh V, Mayer T, Salanitri J, Salinger MH (2007) Cardiac MRI documented left ventricular thrombus complicating acute Takotsubo syndrome: an uncommon dilemma. Int $\mathbf{J}$ Cardiovasc Imaging 23:591-593

60. Syed IS, Prasad A, Oh JK et al (2008) Apical ballooning syndrome or aborted acute myocardial infarction? Insights from cardiovascular magnetic resonance imaging. Int $\mathrm{J}$ Cardiovasc Imaging 24:875-882

61. Patrignani A, Di Cesare E, Cicogna S (2009) Echocardiography and cardiovascular magnetic resonance diagnostic role in Takotsubo cardiomyopathy. Int J Cardiovasc Imaging 25:109-112 